\title{
EFFECT OF DRUMSTICK (MORINGA OLEIFERA LAM) LEAVES ETHANOL EXTRACT ON ANOPHELES ACONITUS L. THIRD INSTAR LARVAE MORTALITY
}

\author{
Yuzana Maung,,2), Sutartinah Sri Handayani' ${ }^{1}$, Lukman Aryoseto' \\ 1)Faculty of Medicine, Universitas Sebelas Maret \\ 2)Masters Program in Public Health, Universitas Sebelas Maret
}

\begin{abstract}
Background: Synthetic insecticides may have the negative effect to nature. Many studies suggested the applications of botanical larvicides as an alternative replacement for synthetic insecticides. This study aimed to examine the effect of Moringa oleifera Lam leaves ethanol extract on the Anopheles aconitus L. third instar larvae mortality.

Subjects and Method: This was a laboratory experimental with post-test only con-trol group design conducted at Salatiga, Central Java, in November 2016. A total of 150 Anopheles aconitus L. third instar larvae was selected by convenience sampling method and divided into 6 groups in which contained replication of 25 larvae. One negative control group was added $100 \mathrm{ml}$ distilled water. The other treatment groups were $1 \mathrm{mg} / 100 \mathrm{ml}, 10 \mathrm{mg} / 100 \mathrm{ml}, 20 \mathrm{mg} / 100 \mathrm{ml}, 30 \mathrm{mg} /$ $100 \mathrm{ml}$, and $40 \mathrm{mg} / 100 \mathrm{ml}$ of Moringa oleifera Lam leaves ethanol extract. Each test group was repeated four times. The dependent variable was mortality of the larvae. The independent variable was different concentrations of Moringa oleifera Lam leaves ethanol extract. The observation of larvae mortality was conducted after 48 hours of exposure with extract. The data were analyzed by Kruskal-Wallis.
\end{abstract}

Results: Mean of the mortality of Anopheles aconitus L. third instar larvae was dif-ferent in each group, and it was statistically significant $(\mathrm{p}=0.008)$.

Conclusion: Moringa oleifera Lam leaves ethanol extract has effect on mortality of Anopheles aconitus L. third instar larvae.

Keywords: Moringa oleifera Lam, Anopheles aconitus L., ethanol extract, mortality

\section{Correspondence:}

Yuzana Maung. Masters Program in Public Health, Universitas Sebelas Maret. Jl. Ir. Sutami 36A, Surakarta, 57126, Central Java, Indonesia. Email: yuzmg5699@student.-uns.ac.id. Mobile: +6281295346614 .

The $7^{\text {th }}$ International Conference on Public Health

Solo, Indonesia, November 18-19, 2020 427 https://doi.org/10.26911/the7thicph.05.59 